\title{
ПОРІВНЯЛЬНЕ ЛІТЕРАТУРОЗНАВСТВО
}

УДК 821.161.2-311.6

DOI https://doi.org/10.32838/2663-6069/2020.3-3/08

Мізінкіна О.О.

Одеський національний університет імені I. І. Мечникова

Чмир А. В.

Одеський національний університет імені I. I. Мечникова

\section{ІНТЕРПРЕТАЦІЯ ВАСИЛЯ-КОСТЯНТИНА ОСТРОЗЬКОГО В СУЧАСНІЙ УКРАЇНСЬКІЙ ІСТОРИЧНІЙ РОМАНІСТИЦІ («ШЕСТИДНЕВ, АБО КОРОНА ДОМУ ОСТРОЗЬКИХ» П. КРАЛЮКА ТА «ШАЛЕНІ ШАХИ» Т. Й О. ЛИТОВЧЕНКІВ)}

У статті розглянуто специфіку образу Василя-Костянтина Острозького в романах «Шестиднев, або Корона дому Острозьких» Петра Кралюка та «Шалені шахи» Тимура й Олени Литовченків. Проиитовано дослідження (П. Білоуса, С. Дзюби, В. Назарук, О. Сагана, С. Синюка, Р. Харчук) твору П. Кралюка, у яких наголошується на його номінуванні, композиції, сюжеті, історичній правді, нарачії. Установлено, щя «Шалені шахи» менше вивчено й у перших відгуках (Л. Зінченко, Л. Чурсиної) підкреслюється реалістичність образів у творі. Визначено, що поєднує романи: зображення епохи XVI cm. $i$ змалювання постаті В.-К. Острозького.

Метою розвідки є встановлення особливостей образу князя в «Шестидневі» П. Кралюка та «Шалених шахах» Т. й О. Литовченків. Для досягнення поставленої мети обрано провідним історико-порівняльний метод, також допомогла методологія інтерпретації тексту, використання культурно-історичного методу.

Аналіз здійснювався на трьох рівнях романів (семантика заголовків, жанрові особливості, характер В.-К. Острозького), які стали визначальними для творення різних образів однієі особистості. Виявлено, що назва твору П. Кралюка більше зосереджена на постаті князя, тоді як у «Шалених шахах» Т. й О. Литовченки на перший план подають тогочасних впливових володарів. Свою кониепиію бачення подій XVI cm. письменники передають завдяки популярній у той час грі, у якій фігура Острозького була однією з головних. Розглянуто жанрову своєрідність обох творів. 3'ясовано, що «Шестиднев» можсна визначити як історично-психологічний роман або роман-сповідь, оскільки образ Острозького постає завдяки його функиї наратора оповіді та прийомам снів, спогадів, внутрішньому мовленню, візуальним засобам невербальної комунікачії, інтонації, психологічному портрету й пейзажу. Динамічний сюжет і пригодницькі ризиковані ситуаиії в «Шалених шахах» дають уналежнити його до різновиду авантюрно-історичного роману. Проаналізовано специфіку характеру Острозького в обох творах. Установлено, що в романі П. Кралюка образ князя постає психологічно поглибленим, тоді як у «Шалених шахах» Василь-Костянтин має деякі ознаки авантюрного героя. Виділено основні риси вдачі Острозького в «Шестидневі». Підкреслено важливу роль критичних міркувань художника щодо діянь князя. Визначено суттєві риси характеру Василя-Костянтина у творі Т. й О. Литовченків. Наголошено, що в «Шалених шахах» вагому роль у сприйнятті образу Острозького відіграють його характеристики іншими персонажами.

Отже, письменники в романах моделюють різні часові проміжки в житті князя; у художніх світах творів надають йому неоднакову роль (головний герой чи один із головних героїв); звертають увагу на психологію Василя-Костянтина або зовнішні ситуаиії, які розкривають характер останнього. 3'ясовано, ще в «Шестидневі» Острозький постає позитивним героєм, натомість у «Шалених шахах» у його образі переважають негативні риси.

Ключові слова: образ, Василь-Костянтин Острозький, роман, характер, П. Кралюк, Т. й О. Литовченки, заголовок, жанр. 
Постановка проблеми. Сучасна українська історична романістика характеризується тим, що письменники активно переосмислюють минуле, відроджують забуті сторінки історії. Однією 3 постатей, яка була художньо потрактована 3 погляду XXI ст., став князь Василь-Костянтин Острозький (1526-1608). Думки майстрів слова щодо його діяльності не є однозначними. У 2010 р. вийшов друком один із перших романів у новітній історії про вищевказаного діяча - «Шестиднев, або Корона дому Острозьких» Петра Кралюка. Продовженням вивчення ролі та значення постаті Василя-Костянтина в історії становлення української держави стали «Шалені шахи» (2014) Тимура й Олени Литовченків.

Аналіз останніх досліджень і публікацій. Варто зауважити, що «Шестиднев» уже тривалий час $\epsilon$ предметом розгляду багатьох літературознавців. Так, Вікторія Назарук звертає увагу на номінування в романі П. Кралюка: «Назви частин (умовно - розділів) граматично $є$ номінативними реченнями, у яких превалюють назви кольорів. Це вирізняє твір «Шестиднев, або Корона дому Острозьких» від традиційних історичних романів, які діляться на класичні розділи чи частини» [10]. На переконання дослідниці, П. Кралюк у такий спосіб суттєво трансформував класичну історичну романістику.

Велику міру реалістичності героїв твору, яка зумовлена історичною правдою та відтворенням їхнього внутрішнього світу, підкреслює Сергій Синюк («Усі персонажі «Шестиднева» - живі люди, а не картонні фігурки з підручника. Тому в романі знайшлося місце не тільки подіям і вчинкам, а й почуттям» [14]). Думка колеги по перу свідчить про те, що П. Кралюку в художній формі вдалося передати образ людини XVI ст.

За жанровими ознаками «Шестиднев» також $\epsilon$ специфічним. Роксана Харчук відзначає, що роман П. Кралюка «належить до історичного жанру, хоча композиційно й у назві співвідноситься із шестидневом, твором філософськобогословського характеру, що пояснює світобудову 3 погляду християнського вчення. Зазвичай шестиднев (найвідоміший - Василя Великого) складається із шести трактатів, що відповідають шести дням сотворіння світу. За аналогією у романі Петра Кралюка ідеться про сотворіння світу українського - держави Острожчини, збудованої Василем-Костянтином Острозьким» [17]. Назва твору «Шестиднев» $є$ концептуально зумовленою та позначена інтертекстуальністю.

На оригінальний прийом оповіді - від головного героя - звернув увагу Петро Білоус. Пись- менник, «зважаючи на те, що пише не історичний трактат, а художній твір, вкладає тлумачення подій та осіб в уста князя Острозького, чим визначає художній ракурс інтерпретації історії. Водночас такий прийом домальовує образ самого князя, який стає джерелом усвідомлення історичного часу і себе та своїх сучасників у ньому» $[1$, с. 10]. Постать Василя-Костянтина в романі стає уособленням тогочасної епохи.

Вищезазначену думку підтверджують міркування Олександра Сагана. Дослідник пише про те, що «життя цього князя - це фактично життя України XVI століття. Люблінська та Берестейська унії, зародження та розвиток козаччини, Острозька академія, Острозька Біблія - ці та інші суспільні й релігійні явища могли б відбутися зовсім інакше, якби не особливий погляд на них некоронованого короля України-Руси Василя-Костянтина Острозького» [13]. Переконуємося, що князь дійсно був непересічною та впливовою особистістю в історії нашої держави.

На своєрідність сюжету роману вказує Сергій Дзюба: «Василь-Костянтин Острозький, відчуваючи наближення смерті, замовляє слузі-малярові Івану - свій портрет. Причому художник мусить намалювати князя впродовж шести днів. Митець мерщій береться до роботи, а «монарх», позуючи йому, пригадує все своє звитяжне і водночас таке стражденне життя» [2, с. 131]. Прикметно, що у творі П. Кралюка образ Василя-Костянтина перебуває на першому плані, він постає основним наратором оповіді.

Роман «Шалені шахи» ще чекає на фахові прочитання та літературознавчі дослідження. Сьогодні в інтернет-джерелах з'являються відгуки вдячних читачів. Зокрема, Лілія Зінченко дає високу оцінку художнім якостям твору Т. й О. Литовченків («Написано легко, літературною мовою, дотепно і цікаво. На відміну від звичайних підручників та сухих фактів, кожен образ героя прописаний досить чітко. Деякі дії головних та другорядних героїв обгрунтовані, що дозволяе бачити та сприймати їх мов живих...» [4]). Схожу думку щодо реалістичності роману Т. й О. Литовченків висловлює в рецензії й Лідія Чурсина: «Герої книги та події, що описані у романі настільки гарно прописані, що складається враження, ніби ти присутній при всіх баталіях, що відбуваються» [18].

Як бачимо, «Шестиднев» більше вивчено, ніж «Шалені шахи». Літературознавці звертають увагу на композицію, героїв, жанр, сюжет, номінування у творі П. Кралюка. Дослідники 
підкреслюють, що постать Василя-Костянтина Острозького посідає в «Шестидневі» виняткове місце. У відгуках на «Шалені шахи» наголошується на тому, що Т. й О. Литовченки у творі ретельно попрацювали над відтворенням кожного образу.

Романи поєднує висвітлення епохи XVI ст. 3 багатьма історичними подіями та провідними діячами. В обох творах особливу увагу привертає образ Василя-Костянтина Острозького. У творі П. Кралюка він є головним героєм, письменник використовує прийом спогадів князя як основний для художньої інтерпретації історичних фактів. $\mathrm{y}$ «Шалених шахах» Т. й О. Литовченків образ Острозького не є першорядним, натомість він сприяє передачі родинної атмосфери та зв'язків із провідними фігурами творення політики в тодішній Європі.

Постановка завдання. Мета статті полягає в з'ясуванні специфіки образу Василя-Костянтина Острозького в «Шестидневі, або Короні дому Острозьких» П. Кралюка та «Шалених шахах» $\mathrm{T}$. й О. Литовченків. Порівняльний метод допоможе встановити спільне, відмінне та окреме в досліджуваному художньому явищі на різних рівнях романів.

Виклад основного матеріалу. Заголовки. У художньому світі твору всі чинники змісту й форми впливають на сприйняття образу. Заголовки романів постають одними 3 перших емоційно-впливових факторів вираження концепції митців і творення образу Острозького. Варто наголосити, що обидва твори мають різні смислові акценти в назвах. «Шестиднев, або Корона дому Острозьких» підкреслює часову обмеженість оповіді для Василя-Костянтина (6 останніх днів його життя). Водночас друга частина заголовка $є$ свідченням важливої місії головного героя, який продовжував справу своїх славетних предків, розбудовуючи державу.

У заголовку роману Т. й О. Литовченків спостерігається прозоре відсилання до гри в шахи, у якій фігура Острозького є однією із сильних. Означення «шалені» має дещо негативний відтінок, який реалізується у світі твору в значенні надмірного керування долями людей. Ключ до розуміння поетики заголовку прихований у двох главах («шахових партіях»), які розпочинають першу i другу частини роману. «Шахова партія № 1. Сила королеви» розповідає про юного англійця, який став переможцем шахового турніру. За умовами цього змагання, парубок має зробити передбачення щодо тієї країни, про яку захоче дізнатися його супротивник. Англієць пророкує, що важливу політичну роль у Польщі відіграє королева. У наступних главах роману письменники показують значення королеви Бони Сфорци (1494-1557) у житті польських королів Сигізмунда I Старого (1506-1548) і Сигізмунда II Августа (1520-1572), у долях Беати Костелецької (1515-1576) та Іллі Острозького (1510-1539), Гальшки Острозької (1539-1582) та Дмитра Сангушка (1530-1555). Саме події, пов'язані із цими персонажами, творять основні сюжетні лінії на початку твору.

«Шахова партія № 2. Пішак, що не став ферзем» зображує переможця минулого шахового турніру в похилому віці, і цього разу він грає з єпископом. Священнослужитель, здавшись і при цьому порушивши правила змагання, передбачає, що в Польщі ватажок бунтівників не зможе стати королем. У такий спосіб єпископ натякає на Северина Наливайка, діями якого намагався керувати Василь-Костянтин Острозький. Князь у романі виступає в ролі гросмейстера, який суттєво впливав на індивідуальне буття окремих особистостей (Дмитра Сангушка, Гальшки Острозької, Дем'яна Наливайка, Беати Костелецької) та суспільне життя правобережної України. Оскільки шахи були популярними в епоху $[19$, с. 7], що описується в романі Т. й О. Литовченків, письменники в основу композиції поклали принципи цієї гри. Фігурами шахів постали реальні історичні особистості та вигадані персонажі.

Отже, назва роману П. Кралюка відсилає до роду Острозьких, що звужує коло головних персоналій, тоді як у «Шалених шахах» адресація є набагато ширшою. Стратегом на політичній і культурній арені Європи XVI ст. був не лише князь ВасильКостянтин Острозький і члени його родини.

Жанрова своєрідність. Оригінальність образу Острозького зумовлена й жанровими особливостями романів. В. Назарук підкреслює, що, «характеризуючи свій витвір, автор визначає його жанр як інтелектуальний роман. До цієї характеристики хочеться ще додати означення - історичнопсихологічний роман-розуміння. Подібне твердження виникає із аналізу архітектоніки тексту. Роман складається із передслів'я, шести окремих частин, озаглавлених специфічною колористикою, і післяслова. Символіка шести пов'язаних між собою частин твору - асоціація із біблійною легендою про час сотворення світу. Шість днів митець малював портрет князя, і шість днів князь пригадував події, що мали місце у шести знакових для роду Острозьких містах» [10]. Для роману П. Кралюка насамперед характерні такі риси, як історизм, епічність, етичний конфлікт, що розкривається через психологічні прийоми зображення 
головного героя. Відтак «Шестиднев» можна уналежнити до такого жанрового різновиду, як роман-сповідь. За аналогією до роману Павла Загребельного «Я, Богдан» (1983) твір П. Кралюка демонструє шлях осмислення своїх праведних і грішних діянь героя історичних подій. Тому в тексті роману Острозький є розповідачем, а в структуру «Шестиднева» введено його сни, спогади і внутрішнє мовлення, що зумовлює велику міру психологізму. Читач безпосередньо знайомиться 3 думками, напрямом мисленням головного героя. Додаткову функцію виконує художник Іван, який $\epsilon$ критиком діянь Василя-Костянтина. Натомість у «Шалених шахах» наявний оповідач. Увагу приділено не стільки образу Острозького та змалюванню його душевних порухів, скільки відтворенню тогочасної атмосфери постійних інтриг. Водночас читачеві допомагає зорієнтуватися в історичних подіях, що висвітлюються в романі, хронологічна таблиця, яка охоплює 1480-1632 pp.

«Шалені шахи» Т. й О. Литовченків за ознаками наближається до вальтерскоттівського типу історичних романів. Письменники в інтерв'ю стверджують, що із цим твором вони «впевнено вписалися в сучасній українській літературі в нішу авантюрно-історичного роману» [11]. Підтвердження знаходимо в «Літературознавчому словнику-довіднику», де виокремлюється дві провідні ознаки такого твору - динамічний сюжет і пригодницькі ризиковані ситуації [9, с. 9]. Роман Т. й О. Литовченків також входить до козацького циклу («Пустоцвіт», «Кинджал проти шаблі», «Шалені шахи» та «Фатальна помилка»), в основі якого насамперед лежить пригодницьке начало. Відтворені уривки життя Острозького постають одними зі складників картини світу XVI ст.

Характер Острозького. У «Шестидневі» письменник удається до таких прийомів творення образу Василя-Костянтина, як внутрішнє мовлення; сни, марення; сповідь як форма психологічного зображення; візуальні засоби невербальної комунікації; інтонація; психологічний портрет і психологічний пейзаж, тому постать князя $\epsilon$ психологічно поглибленою. Такі способи розкриття образу цього діяча допомагають деталізувати та індивідуалізувати останнього. У творі Т. й О. Литовченків Острозький близький до авантюрного героя. На думку Світлани Кучіної, «це образ людини, яка вищою мірою залежить від випадку чи втручання вищих сил, чи то надприродних сил, чи то таємничих лиходіїв, чи то благодійників. Він позбавлений ініціативності, лише пристосовується до витівок долі і змушений діяти з урахуванням обставин, що склалися, що, зі свого боку, зберігає незмінність образу героя, його «тотожність» самому собі» (переклад наш О. М., А. Ч.) [7, с. 26]. Василю-Костянтину притаманні такі ознаки авантюрного героя, як залежність від випадку, пристосовництво та пошук шляхів виходу зі складної ситуації з корисними намірами.

У романі П. Кралюка ключовими засобами в розкритті постаті князя є самохарактеристика й оцінка головного героя художником. Письменник відтворює ймовірні ситуації в житті ВасиляКостянтина 3 метою показати риси вдачі останнього. Князь постійно вдається до саморефлексії, що дає змогу звернути увагу читача на змодельовані думки цього діяча. Уже в «Предслів 'і» до твору Острозький подається задумливим і зосередженим. «Маю що згадувати. Можу годинами сидіти в задумі. А перед моїми очима бовваніють лики різних людей. Деякі змаліли, розмилися. Призабулися й діяння людські. Та можна домислити їx, побачити такими, як хочеться. I ніхто мене за те не осудить. То мій світ. I я у нім судія» $[6$, c. 3], - зізнається Василь-Костянтин. Головний герой - людина поважного віку (82 роки), а тому його міркування неодмінно спрямовані на аналіз пережитого.

Наступними рисами характеру, які виразно наявні в образі Острозького, є спостережливість і гордість. Василь-Костянтин, передчуваючи свою смерть, запрошує художника Івана, який має увіковічити князя на портреті. Уперше побачивши митця, головний герой зауважує: «До світлиці заходить маляр. Мій маляр! Невисокого зросту, але добре збитий. Має присмне лище. I - проникливі очі. Низько клонить голову. Що у тій голові - не знаю. Як і не знаю, що ховається в очах його. Та чи потребне мені те знаття? Хто він, той маляр? Простак, хлоп. Таким несть числа. А я-князь! < .. > I поглядає. Знає чоловік собі ціну. Такого майстра нелегко знайти. Вчився в землі німецькій, у влохів» [6, с. 3-4]. Високий соціальний статус князя зумовлює владність у його міркуваннях. Розмовляючи з художником і наказуючи йому намалювати портрет, головний герой визнає, що «залізні нотки забриніли в моєму голосі» [6, с. 5]. У «Шестидневі» Острозький зображується досвідченим правителем. Промовистим є епізод, коли маляр критикує предка головного героя - Василя Красного (?-1453) за недостатню розбудову оборонних споруд. Після цієї необачної репліки художника Василь-Костянтин зазначає, що «я не серджусь. Що він розуміє? Молодий» [6, с. 82]. 
У романі головний герой згадує про свого підданого Герасима Смотрицького (?-1594), який перед смертю пробачив князю його не завжди праведні вчинки. Острозький стверджує, що «я теж, коли йтиму зі світу иього, прощу всіх, хто мені зло заподіяв. I подякую тим, хто зробив добро» [6, с. 190]. Вищевказані слова вказують на благородство цього діяча. Василь-Костянтин $є$ побожним, адже, займаючись державними справами, він не забуває про служіння Богу. Головний герой зізнається, що «не є аз грішником великим. Правил християнських дотримую. На час великого посту іду в монастир молитися, життя проваджу тод $i$ своє, як чернець-покутник. Отиів духовних не зобижаю. Гроші на храми, монастирі даю. Особливо на монастир Печерський, де багато предків моїх спочинок знайшли» [6, с. 67].

Князю притаманна така риса характеру, як уміння знаходити спільну мову з різними особистостями. Історики (Микола Костомаров [5], Іван Огієнко [11], Григорій Савчук [12] та ін.) свідчать, що задля створення Острозької Біблії (1581р.) він зміг порозумітися 3 такою непересічною людиною, як Іван Федоров (?-1583). Запросивши до себе в Дубно відомого друкаря й познайомившись із ним, головний герой розмірковує: «Непростий ти чоловік, Іване Федоровичу, - думалося мені. - Непосидючий. I думки високої про персону власну. А може, то й добре. Бо інакще ким би ти був? Купием - як твій отеиь? Таких доволі є. Чи гречкосієм? Таких іще більше. Нелегко, чує моя душа, буде з тобою. Але нехай! Коли щось легко дається - то гріш тому ціна» [6, с. 175]. Василь-Костянтин не тільки мудрий і розумний, а й хитрий. Красномовним $\epsilon$ той факт, що під час спроби католиків надіслати до Острозької академії своїх учителів головний герой, убачаючи в цьому загрозу православній вірі, вирішує заплутати сліди. Згадуючи про тогочасні події, князь розповідає, що «мій син та мої люди доносили папському посланцю зовсім різні речі про мене. Одні говорили, ніби я заклятий схизматик $і$ з Римом не порозуміюся. Інші, навпаки, твердили, щяо прагну згоду з папіжниками знайти. Бідний латинник не знав, кому вірити $і$ як то є насправді» [6, с. 195].

Варто підкреслити, що головному герою властиві такі полярні риси характеру, як рішучість і пасивність. Берестейська унія (1596 р.), яка суттєво посилила релігійні проблеми і стала причиною появи греко-католицької церкви, глибоко схвилювала Острозького. Василь-Костянтин на православному соборі приймає сміливе рішення про те, що «не даємо згоди на нову віру, не відкида- ємо православ'я, ні віри предків наших, не відступаємося від обичаїв та святих догм иеркви східної; усі ми, малі і великі, тримаємося ортодоксії, якої непохитно наші предки трималися, задля неї не пошкодуємо не тільки маєтності, імені й будьякого багатства світу иъього, а й жінок, $і$ дітей, $i$ дочасного свого життя» [6, с. 158]. Водночас князь менш активний у політичних питаннях, ніж у релігійних. Цілком можливо, що головний герой утратив можливість стати монархом Речі Посполитої. «Мені говорили, щуоби $і$ аз, грішний, подав персону свою на елекцію королівську. Я знизував плечима. Казав: ви вірите, щчо поляки й литвини оберуть православного русина. Навіщо мені иі клопоти?» [6, с. 123-124], - розмірковує Острозький.

Для Василя-Костянтина також характерна чутливість. Князь співчуває трагічній долі своєї племінниці Гальшки Острозької, яка тужить за своїм першим померлим чоловіком Дмитром Сангушком. Головний герой, побачивши через багато років цю змучену дівчину й відчуваючи деяку провину в загибелі іiї нареченого, зізнається, що «чомусь мої очі зволожуються» [6, с. 59]. Розповідаючи про полоненого російською армією батька - Костянтина Острозького (1460-1530), князь визнає, що «на душі гіркота» [6, с. 89]. Коли у Василя-Костянтина померла його дочка Катерина (1560-1579), у нього «потемніло в очах. Світ став немилий» [6, с. 119]. Після загибелі свого сина - Олександра Острозького (1570-1603) - головний герой утрачає свідомість ( $І$ с світ почорнів, як смола. I я падаю у безодню» [6, с. 166]). Коли він уболіває за майбутнє Северина Наливайка (?-1597), який перебував у польській в'язниці, на очі князя «навертаються сльози» [6, с. 238]. Особливо показовою в романі є сцена, у якій Василь-Костянтин ховає свою дружину Софію Тарновську (1534-1570): «Я стояв біля труни. I підігнулися в мене ноги. І упав я на коліна. I сльози текли з очей моӥх. Дорослий муж - а плакав, як хлопчик. "Не уберіг Софію», гризла така думка. Дивився на мертву дружину, ї обличчя. Змарніло воно. Але все одно моя Софія найкраща» [6, с. 130]. За дослідженнями істориків (Василь Ульяновський [16] та ін.), Острозький дійсно кохав свою дружину, а тому надзвичайно болісно переживав її смерть.

Додатково розкривають образ Василя-Костянтина міркування про нього художника. Думки людини, яка близька до народу, дають змогу читачеві відсторонено поглянути на постать головного героя і критично іiі осмислити. Маляр, знайомлячись з Острозьким, засуджує схильність до 
гедонізму та прагнення до побутових зручностей: «Немає, княже, в тебе віри міиної. Любиш життя сьогосвітне, вигоди його. Правда, хто не любить? I прагнеш, княже, лишитися в світі цьому земному - хоча б на портреті» [6, с. 5]. Художник помічає, що Василь-Костянтин часто $€$ доволі замкнутим та обережним («Хочу вималювати контури лиия свого пана. Воно й далі незворушне. «То ж маска», - кажу собі» [6, с. 29]; «Я вже зобразив обриси князя. Залишилися очі. Та не можу їх змалювати - ховаються вони» [6, с. 49]; «Ворушаться вуста князя. Щось говорить. Але собі. Не хоче ділитися таӥнами» [6, с. 52]; «Хоча незворушне в тебе, князю, лице, але голос... Видається: чую в ньому біль великий〉 [6, с. 89]). Очевидно, що не все портретований розповідає художникові.

Маляр уважає, що Острозький опосередковано винний у смерті Дмитра Сангушка й нещасті Гальшки: «А ти безгрішний, мій пане? I немає твоєї вини в смерті князя Димитрія? I не ти попсував життя Гальшки? Тільки пошлюбили вже удова» [6, с. 43]. Художник припускає, що головний герой, скориставшись послугами Івана Федорова, потім спровадив останнього: «Чи не лукавиш, князю? Знаю: вигнав ти Івана-друкаря в три шиї, як той роботу свою зробив» [6, с. 175]. Маляр засуджує Василя-Костянтина за те, що цей діяч використовував і наражав на небезпеку Северина Наливайка в корисних цілях: «Захотілося тобі на двох стільиях посидіти - з турком повоювати, иісарю, папі сподобатися, $i$ з королем не посваритись. Тому ти Наливаю позволив збирати людей, щзоби на турка, татарина йти. Добре, князю, чужсими руками жар загрібати!» [6, c. 218].

Завдяки спостереженням художника помітна ще така риса вдачі Острозького, як деяка інертність. На думку маляра, головний герой деякою мірою $є$ жертвою гіперопіки рідних у дитинстві («Зіпсувала тебе, княже, материнська опіка. Надмірная! Тепер ти -як гора. Великий! Велетенський! Видаєшся могутнім. Але стоїш на місиі» [6, с. 18]). Художник помічає, що Василю-Костянтину більше до вподоби домашне буття, аніж участь у суспільних подіях: «Ти, князю, домосід. Не хочеш, як твої пращури, иукати слави в чужих краях, завойовувати їх. Такі люди не будують імnерій» [6, с. 85]. Коли головний герой розповідає про ідею створення Острозької Біблії, маляр відзначає наполегливість цього діяча («Видать, затявся ти, княже. Хочу зобразити на личі твоєму ту впертість. Чи - силу? Вперту силу»
[6, с. 177]). Перед смертю Василя-Костянтина художник звертає увагу на його фізичну слабкість і водночас душевну доброту: «Поганий вигляд у нього - ніби всі біди, страждання, які зазнав він у житті свосму, враз звалилися на нього. Через силу посміхається. Та в очах його - доброта» [6, c. 254].

У романі «Шалені шахи» Т. й О. Литовченків ключову роль у моделюванні образу Острозького відіграють авторські характеристики та оцінки князя іншими персонажами. Письменники наголошують, що в підлітковому віці Василь-Костянтин був розбалуваним, примхливим, безцеремонним і грубим хлопчиком. Показовою $є$ ситуація, що після одруження свого старшого брата Іллі Острозького на Беаті Костелецькій «розпещений молодик спробував відтіснити від князя молоду дружиноньку» [8, с. 25]. Непростий характер княжича підкреслює і його паспортний портрет. Побачивши Василя-Костянтина, який через деякий час повернувся 3 Турова до Острога, Ілля фіксує, що «хлопець підріс настільки, щзо виглядав набагато старшим за свої тринадиять років. Хвилясте світло-каштанове волосся, рухливе симетричне обличчя, пухкі червоні губи й рожеві щоки викликали цілком позитивні емоції. Його чарівливість псував хіба що занадто рухливий i якийсь надто примхливий погляд світлих ясних очей...» $[8$, с. 25]. Письменники показують процес формування характеру нащадка відомого роду Острозьких.

Ще будучи підлітком, Василь-Костянтин демонструє такі риси вдачі, які притаманні сформованим особистостям. Коли Ілля почав нездужати, Василь-Костянтин виявився надзвичайно турботливим, оскільки він «негайно засмутився $\check{u}$ иілковито занурився у смуток, як ие властиво тільки дорослим. Навіть на поборозненому зморшками обличчі Іллі Костянтиновича неможливо було виявити таких явних ознак туги и суму, як на юному личку княжича! Здавалося, від гарячого, щирого співчуття він на очах перетворюється в маленького дідка, убитого горем... День за днем Василь Костянтинович просиджував у кутку біля вікна, підперши кучеряву голівку випещееними мініатюрними ручками й мовчки розглядаючи брата» [8, с. 25]. Як бачимо, хлопець справді переживав за долю Іллі. Важкохворий брат Василя-Костянтина, обговорюючи 3 другом родини Федором Сангушком (?-1548) свій заповіт, характеризує княжича як досить кмітливого хлопця: «Молодий, але досить розумний» [8, c. 31]. Однак в Острозького наявні прагнення 
до влади й честолюбство. У романі зазначено, що ще змалечку «княжич Василь вважав себе законним спадкоємием острозьких володінь: про це говорили всі, включно з його матінкою. Незважаючи на свої тринадиять років, княжич вже відчував честолюбне бажання бути хазяїном. Його охопив азарт володіння, немовби вершника, який збирався скочити на необ'їждженого норовистого коня $i$, оком не моргнувщи, привселюдно приборкати його самою лише силою волі. Княжич розраховував, досягнувши повноліття, стати дуже заможним $і$ великим, затьмарити славу батька й діда! Марив стати власником не тільки Острога, але й усіх земель литовських... а можливо, навіть польських!..» [8, с. 103-104].

Дорослий князь виступає в романі політичним інтриганом. Усвідомлюючи, що братова дружина Беата закохана в Дмитра Сангушка, Василь-Костянтин послуговується цією ситуацією («Часто Острозький використовував вроду князя Сангушка, щоб отримати від Беат позачергову суму для так званих «добрих справ» [8, с. 36]). Князю притаманний аморальний прагматизм, оскільки він прагне позбутися сина Гальшки, який у майбутньому буде претендувати на спадщину. Для цього Василь-Костянтин пропонує Беаті «прилаштувати «незручну» дитину кудись на сторону» [8, с. 73].

Князь постає меркантильним, тому що рахує кожну копійку, яку Гальшка віддає на благоустрій Острога («Князь сумовито й нервово озирався довкола, подумки підраховуючи витрати княгині на прикрашення Острога, на будівельні роботи тошо. Тільки одна думка заповнювала його мозок: «Скільки ж грошей викинула на вітер княгиня? Скільки МОЇХ грошиків пропало?..»»» [8, с. 114]). Письменники припускають, що саме Гальшка була ініціаторкою створення в 1576 р. відомої Острозької академії. Василь-Костянтин схильний до лицемірства. Вельми красномовною в романі є сцена, коли Северин Наливайко вирішує залишити службу сотника надвірної корогви Острозького, щоб іти воювати з татарами. Князь, розмовляючи зі своїм підлеглим та обіцяючи йому грошову допомогу, визнає, що «просто втомився лицемірити перед иим кришталево чесним, хоча й недоумкуватим чоловіком. Таке в житті старого князя ставалося нечасто... але всетаки іноді ставалося» [8, с. 201-202]. Більшість характеристик свідчить про негативні риси вдачі Василя-Костянтина.

Оцінка князя іншими персонажами також $\epsilon$ осудливою. Беата, дізнавшись про те, що Дмитро Сангушко підтримує діалог з Острозьким, звинувачує в цьому парубка: «- Дмитре Федоровичу, я звернулася до вас за порадою, як до друга! А ви, виявляється, за моєю спиною обговорюєте намі розмови із иим істериком?! Я з такими зусиллями вирядила князя в Дубно, щоб узагалі не бачити й не чути цьвого негідника!.. Іноді терплю його присутність в Острозі тому лише, щзо князь вирішує фінансові питання, у яких я анічогісінько не тямлю!.. Так, я терплю Василя Костянтиновича, оскільки обічяла покійному чоловікові не сваритися з його братом» [8, с. 37]. Схожої невисокої думки про свого дядька була й Гальшка: «Та й князь Василь Костянтинович, виявляється, ще той негідник: пожертвував життям свого племінника Семена, щэоб отримати Острозький замок від Беат...» [8, с. 122].

Визначальними $€$ й слова сина князя - Януша Острозького (1554-1620), які адресовані своєму отцю: «-Батьку, а вам не набридло поширювати плітки? Ви б Бога побоялися, чи щео.. <... Права була моя матінка, коли називала вас бездушним тираном, охопленим настирливою ідеєю володіння!!! Скільки сил віддаєте ви иій марній битві за спадщину - не збагнути!!! Ви мерзенний i бридкий, батьку, як $і$ всі ваші думки й діяння, народжені в запалі інтриг і пристрастей!.. Ви ж навіть не помітили, як згасла ваша дружсина, моя матінка Зофія. Не бажаєте чути, як страждаємо без вашої уваги ми - ваші сини. А Олена... Вона прекрасна й чиста, немов янгол небесний! Якщо ви, батьку, захочете скривдити ї, то на мою допомогу навіть не розраховуйте. Упокортеся, доки не пізно! Попереджаю по-доброму» [8, с. 106-107]. Василь-Костянтин зображується жорстоким правителем, якому байдуже на смерть своєї дружини Софії і страждання членів родини Острозьких. У тексті твору наявні ще такі показові авторські характеристики цього діяча, як старий хитрун [8, с. 144], старий лис [8, с. 144] і скупий князь [8, с. 145]. Прикметно, що лис є символом «лицемірства, лукавства та улесливості, хитромудрощів, злодійкуватості й хижацтва, влізливості, хвалькуватості, скритності та обережності, чуткості, нечесності» [3, с. 444]. Як бачимо, Т. й О. Литовченки витворюють постать ВасиляКостянтина переважно з негативними рисами.

Висновки і пропозиції. Отже, письменники по-різному представляють образ Острозького. Якщо П. Кралюк подає останні дні життя князя, то Т. й О. Литовченки показують його у віці від 13 до 71 років і неодноразово звертають увагу читача на його непростий характер. У «Шестидневі» Василь-Костянтин, беззаперечно, $\epsilon$ головним 
героєм, тоді як у «Шалених шахах» він - один із головних героїв. У творі П. Кралюка акцент зроблено на психології Острозького, яка забезпечується спогадами, снами, мареннями, внутрішнім мовленням і психологічним портретом героя. Критичний погляд на вчинки князя подається завдяки міркуванням художника Івана. Натомість у «Шалених шахах» постать цього діяча розкривається переважно завдяки змалюванню ситуацій, які характеризують його. Такий прийом подачі героя свідчить про те, що в романі Т. й О. Литовченків князю притаманна авантюрність, пристосуванство та лицемірство.
У «Шестидневі» Василь-Костянтин, осмислюючи свої вчинки, виступає переважно позитивним героєм. 3 погляду художника подається критична оцінка деяких вчинків князя, що увиразнює образ останнього. Такий спосіб зображення Острозького є спробою неупереджено поглянути на постать цього українського діяча XVI ст. Натомість в образі Василя-Костянтина, що постає в «Шалених шахах», превалюють негативні характеристики. В Острозького наявна патологічна жадоба до влади і збагачення. Унаслідок князь залишається самотнім, покинутим і незрозумілим.

\section{Список літератури:}

1. Білоус П. Шість днів і все життя князя Острозького. Літературна Украӥна. 2011. № 11. С. 10.

2. Дзюба С. Рец. на книгу: Кралюк П. Шестиднев, або Корона дому Острозького: Роман. Сіверянський літопис. 2011. № 2. С. 131-136.

3. Енциклопедичний словник символів культури України / за заг. ред. В. П. Коцура, О. І. Потапенка, В. В. Куйбіди. 5-те вид. Корсунь-Шевченківський : ФОП Гавришенко В. М., 2015. 912 с.

4. Зінченко Л. Ми маємо краще вчити історію! : рецензія. Друг читача. 22.05.2015. URL: https://vsiknygy.net.ua/shcho_pochytaty/41606 (дата звернення: 01.07.2020).

5. Костомаров М. І. Галерея портретів: Біогр. нариси: для серед. та ст. шк. віку / упоряд. і передм. В. О. Замлинського ; пер. з рос. М. М. Ілляш. Київ : Веселка, 1993. 326 с.

6. Кралюк П. Шестиднев, або Корона роду Острозького : роман. Київ : Ярославів Вал, 2010. 320 с.

7. Кучина С. А. Герой в художественной структуре классического авантюрного романа. Lingua mobilis. 2010. № 3 (22). С. 25-31.

8. Литовченко Т. І., Литовченко О. О. Шалені шахи. Харків : Фоліо, 2014. 315 с.

9. Літературознавчий словник-довідник / за ред. Р. Т. Гром’яка, Ю. І. Коваліва, В. І. Теремка. Київ : Академія, 2007. $752 \mathrm{c.}$

10. Назарук В. М. Про «Шестиднев» Петра Кралюка. Науковий вісник Ужгородської богословської академії імені святих Кирила і Мефодія. Ужгород : Карпатський університет імені Августина Волошина, 2010. URL: http://kulturolog.org.ua/publications/p-reviews/244--qq.html (дата звернення: 01.07.2020).

11. Огієнко I. І. Історія українського друкарства / упоряд., авт. іст.-біогр. нарису та приміт. М. С. Тимошик. Київ : Либідь, 1994. 448 с.

12. Савчук Г. Постать Івана Федорова в контексті московської еміграції у Литву другої половини XVI століття. Наукові зошити історичного факультету Львівського університету. 2012-2013. Вип. 13-14. С. 17-31.

13. Саган О. «Шестиднев, або Корона дому Острозького». Релігійно-інформаиійна служба Украйни. 2010. 22 листопада. URL: https://risu.org.ua/ua/index/studios/announcements_of_publications/39149 (дата звернення: 01.07.2020).

14. Синюк С. «Шестиднев» Петра Кралюка. День. 2011. 4 лютого. № 19. URL: https://day.kyiv.ua/uk/ article/ukrayinci-chitayte/shestidnev-petra-kralyuka (дата звернення: 01.07.2020).

15. Тимур і Олена Литовченки: колективний розум : інтерв'ю. Національна спілка письменників Украӥни НСПУ / розмовляла Е. Заржицька. 12.09.2017. URL: https://nspu.com.ua/interv-yu/timur-i-olena-litovchenkikolektivnij-rozum (дата звернення: 01.07.2020).

16. Ульяновський В. Князь Василь-Костянтин Острозький: історичний портрет у галереї предків та нащадків. Київ : Простір, 2012. 1370 с.

17. Харчук Р. Роман про історичну й духовну сліпоту. ЛітАкиент. 2011. 10 лютого. URL: http://itakcent.com/2011/02/10/roman-pro-istorychnu-j-duhovnu-slipotu (дата звернення: 01.07.2020).

18. Чурсина Л. Від читачів: Історія як партія у шахи («Шалені шахи», Тимур та Олена Литовченки). Катрусин книгозал. 12.08.2015. URL: https://knygozal.wordpress.com/2015/08/12/від-читачів-історія-якпартія-у-шахи-ш\%20(дата\%20звернення:\%2001.07.2020.

19. Янків I. Т., Литвинець А. І. Історичні аспекти розвитку шахів в світі та Україні : лекція № 13 навчальної дисципліни «Шахи». Львів, 2019. 28 с. 


\section{Mizinkina O. O., Chmyr A. V. THE INTERPRETATION OF VASYL-KOSTIANTYN OSTROZKY IN MODERN UKRAINIAN HISTORICAL NOVELS ("SHESTYDNEV, OR THE CROWN OF THE HOUSE OF THE OSTROZKY FAMILY” BY P. KRALIUK AND “CRAZY CHESS” BY T. AND O. LITOVCHENKO)}

The article considers the specifics of the image of Vasyl-Konstantin Ostrozky in the novels "Shestydnev, or the Crown of the House of the Ostrozky Family" by Peter Kraliuk and "Crazy Chess" by Timur and Elena Litovchenko. The research (P. Bilous, S. Dziuba, V. Nazaruk, O. Sagan, S. Sinyuk, R. Kharchuk) of P. Kraliuk's work is cited, in which his nomination, composition, plot, historical truth, narration are emphasized. It is established that "Crazy Chess" is less studied and in the first reviews (L. Zinchenko, L. Chursina) the realism of images in the work is emphasized. It is determined that combines the novels of the reconstruction of the $X V I$ century and the creation of personality V.-K. Ostrozky.

The purpose of the investigation is to establish the peculiarities of the image of the prince in P. Kraliuk's "Shestydnev" and T. and O. Litovchenko's "Crazy Chess". To achieve this goal, the leading historicalcomparative method was chosen, and the methodology of text interpretation, cultural-historical method also helped.

The analysis was carried out on three levels of novels (semantics of titles, genre features, the character of V.-K. Ostrozky), which became decisive for the creation of different images of one person. It was found that the title of P. Kraliuk's work is more focused on the figure of the prince, while in "Crazy Chess" T. and $O$. Litovchenko bring to the fore the influential rulers of that time. Writers convey their concept of the vision of the events of the XVI century with the help of a popular game at the time, in which the figure of Ostrozky was one of the main. The genre originality of both works is considered. It has been found that "Shestydnev" can be defined as a historical-psychological novel or a confessional novel, as Ostrozky's image appears due to his role as narrator of narratives and techniques of dreams, memories, inner speech, visual means of nonverbal communication, intonation, psychological portrait and landscape. The dynamic plot and adventurous risky situations in "Crazy Chess" allow you to belong to a kind of adventure-historical novel. The specifics of Ostrozky's character in both works are analyzed. It is established that in P. Kraliuk's novel the image of the prince is psychologically profound, while in "Crazy Chess" Vasyl-Konstantin has some features of an adventurous hero. The main features of Ostrozky's character in "Shestydnev" are highlighted. The important role of the artist's critical considerations regarding the prince's actions is emphasized. Significant features of the character of Vasyl-Konstantin in the novel by T. and O. Litovchenko are determined. It is emphasized that in "Crazy Chess" other characters' opinions about him play an important role in the perception of Ostroh's image.

Thus, writers in their novels model different time intervals in the life of the prince; give him a different role in the texts of works (the protagonist or one of the main characters); pay attention to the psychology of VasilyConstantine or external situations that reveal the character of the latter. It was found out that in "Six Days" Ostrozky appears as a positive hero, while in "Crazy Chess" his character is dominated by negative traits.

Key words: image, Vasily-Konstantin Ostrozky, novel, character, P. Kraliuk, T. and O. Litovchenko, title, genre. 